\title{
Determination of Factors that Impact Adherence to Warfarin in Patients with Stroke
}

\author{
Inmeli Hastalarda Varfarine Uyumu Etkileyen Faktörlerin Belirlenmesi
}

\begin{abstract}
Objective: Oral anticoagulants are the mainstay in the secondary prevention of stroke. Adherence to drug is an important issue in preventing stroke. The aim of this study was to determine the adherence of patients with stroke to warfarin (anticoagulant agent) and to investigate the factors that may impact adherence.

Materials and Methods: This descriptive cross-sectional study was conducted on patients admitted to an outpatient neurology clinic of a tertiary hospital in Istanbul. A total of 99 patients with stroke who were under warfarin treatment for at least 6 months prior to the study were enrolled in the study. Patients were assessed in terms of sociodemographic characteristics, adherence to and knowledge regarding the drug, anxiety and depression, mental and functional state and quality of life using validated scales.

Results: The mean adherence score of the patients was 3.3 $1.1(0-4)$. The reported adherence rates were not considered as low in our sample given that $42 \%$ had poor knowledge. Significant negative correlations were determined between drug adherence and age, number of risk factors, and duration of anticoagulant use ( $r=-$ $0.39, \mathrm{r}=-0.33, \mathrm{r}=-0.52, \mathrm{p}<0.001$, respectively). The mean drug adherence scores were lower in patients who had experienced drug-related adverse effects compared with those that did not $(\mathrm{p}=0.018)$. Significant correlations were found between the adherence scale and all other variables $(\mathrm{p}<0.05)$. Multiple linear regression analysis revealed that drug adherence was predicted by experiencing adverse effects, knowledge regarding the drug, and depression.

Conclusion: Knowledge regarding the use of warfarin was inadequate in our patients, whereas adherence was reported not to be inadequate. The most influential factors that may impact adherence were adverse effects, knowledge, and depression. Healthcare professionals should be aware of patients who have risk factors for non-adherence.
\end{abstract}

Keywords: Stroke, warfarin, oral anticoagulant, adherence

Öz

Amaç: Oral antikoagülanlar inmede ikincil korunmada tedavinin temelidir. İlaç tedavisine hasta uyumu, ikincil korunmada önemli konulardan biridir. Bu çalışmanın amacı inmeli hastaların varfarin (antikoagülan ajan) tedavisine uyumunu ve uyumu etkileyebilecek faktörleri belirlemektir.

Gereç ve Yöntem: Bu tanımlayıcı kesitsel çalışma, İstanbul'da bir ĕ̆itim ve araştırma hastanesinin nöroloji polikliniğinde gerçekleştirilmiştir. Çalışmaya en az 6 aydır varfarin tedavisi almakta olan 99 inmeli hasta dahil edilmiştir. Hastalar sosyodemografik özellikler, ilaç uyumu ve ilaç konusunda bilgi, anksiyete ve depresyon, mental durum, fonksiyonel durum ve yaşam kalitesi faktörleri açısından değerlendirilmiştir.

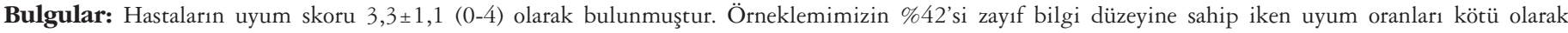
değerlendirilmemiştir. İlaç uyumu ile yaş, risk faktör sayısı ve antikoagülan kullanım süresi arasında istatistiksel olarak anlamlı negatif korelasyonlar saptanmıştır $(\mathrm{r}=-0,39, \mathrm{r}=-0,33, \mathrm{r}=-0,52, \mathrm{p}<0,001$, sırasıyla). İlaç yan etkisi yaşayanların ilaç uyumunun yaşamayanlara göre daha kötü olduğu tespit edilmiştir ( $\mathrm{p}=0,018)$. Tüm diğer değişkenler ile ilaç uyumu arasında anlamlı korelasyonlar bulunmuştur. Regresyon analizinde ilaç uyumunu predikte eden faktörler yan etki yaşama, ilaçla ilgili bilgi ve depresyon olarak saptanmıştır.

Sonuç: Hastaların varfarin kullanımı hakkındaki bilgileri yetersiz iken, uyumun yetersiz olmadığı bildirilmiştir. Uyumun en fazla yan etki yaşama, bilgi ve depresyondan etkilendiği bulunmuştur. Sağlık bakım profesyonelleri, ilaca uyumsuzluk riski olan hastaların farkında olmalıdırlar.

Anahtar Kelimeler: İnme, varfarin, oral antikoagülan, uyum Address for Correspondence/Yazisma Adresi: Zeliha Tülek, Istanbul University Cerrahpasa Florence Nightingale Faculty of Nursing, Istanbul, Turkey
Phone: +90 5327762993 E-mail: tulekz@yahoo.com ORCID: orcid.org/0000-0001-8186-6698

Received/Geliş Tarihi: 02.01.2019 Accepted/Kabul Tarihi: 18.03.2019

This study was presented in $22^{\text {nd }}$ European Stroke Conference as a poster presentation and funded by the Research Fund of Istanbul University (UDP-32468).

${ }^{\circledR}$ Copyright 2019 by Turkish Neurological Society

Turkish Journal of Neurology published by Galenos Publishing House. 


\section{Introduction}

Stroke is one of the most important cause of disability and mortality worldwide. Among stroke subtypes, ischemic strokes comprise $87 \%$ of all strokes and have a high risk for recurrent cardioembolic events. The most common cause of recurrent cardioembolic events after stroke has been reported as atrial fibrillation (AF). The incidence of $\mathrm{AF}$ increases with age, and risk of AF-related stroke increases about 4-5-fold with the addition of other risk factors (hypertension, diabetes, coronary cardiac diseases, cardiac failure) in patients with stroke (1). Furthermore, prophylactic treatment should be initiated to prevent cardiovascular events because AF-related ischemic stroke is more severe, which causes a worse functional state and higher mortality than those related to other etiologies $(1,2,3)$. Oral anticoagulant agents are the mainstay of therapy in secondary prevention. Although numerous oral non-vitamin $\mathrm{K}$ antagonists have been developed in recent years, they have not yet replaced warfarin (vitamin $\mathrm{K}$ antagonist) $(4,5)$. The efficacy of warfarin treatment is related to many variables such as socio-demographics, genetics, the pharmacokinetics of the drug, and patient adherence to the therapy. Among these factors, the adherence of the patient to the drug is the modifiable one.

There are many studies on adherence to warfarin in patients with cardiovascular disease. However, the number of studies is lower in the case of stroke. In the literature, it has been reported that higher educational level, regular social life, being wellinformed about the therapy, strong patient-health professional relationship, and the severity of the disease positively affect the adherence to warfarin therapy, whereas drug-food and drug-drug interactions, concomitant diseases, polypharmacy and psychosocial causes such as anxiety, depression, lack of knowledge or motivation or inability to arrange physician appointments negatively affect adherence $(6,7)$. Although not being very consistent, inadequate adherence to warfarin has shown to be associated with poor anticoagulation control [international normalized ratio (INR) out of targeted therapeutic range] $(8,9)$. Maintaining INR in the targeted therapeutic range (2.0-3.0) increases the improvement in functional outcomes by 2 -fold, it reduces the risk of death after stroke by 2.8 -fold $(1,10)$. An INR value below the targeted limit increases the risk of recurrent venous thromboembolism or stroke, whereas values over the limit may lead to hemorrhagic events that result in excessive bleeding or death. Therefore, optimal management of the treatment includes a correctly prescribed dose regimen that avoids the risk of both thromboembolism and bleeds, and monitoring of the INR value and enhancing patient adherence $(10,11,12)$.

Evaluating factors associated with adherence to warfarin treatment would have clinical importance in enhancing adherence to the drug. The aim of this study was to determine the adherence to warfarin therapy, and to evaluate factors that might affect adherence.

\section{Materials and Methods}

\section{Study Design and Participants}

This descriptive cross-sectional study was conducted on patients with stroke who were admitted to an outpatient neurology clinic of a tertiary hospital in Istanbul. A total of 99 patients with stroke who were under warfarin treatment for at least 6 months, aged over 18 years, able to communicate, and willing to participate were included in the study. Before data collection, ethical approval was obtained from the Ethics Board of the hospital (25.11.2016/892). Written informed consent was obtained from the participants.

\section{Data Collection}

To collect data, a patient information form, Adherence Scale [Morisky, Green, Levine test (MGL)], MedTake test, hospital anxiety and depression scale (HADS), mini mental state examination (MMSE), Barthel index of daily activities, modified Rankin disability scale (mRS), and the EQ-5D (EUROQOL Quality of Life Scale) were used. Data were collected through faceto-face interviews.

Adherence Scale (Morisky, Green, Levine Test): MGL was used to evaluate warfarin adherence. This scale was developed by Morisky et al. (1986) (13) in order to evaluate adherence. The scale consists of 4 questions. The scale is answered as "yes" or "no", and shows the drug adherence of the patient as "high", "moderate", and "poor". The higher the score is, the better the adherence.

MedTake Test: To evaluate the knowledge of patients regarding warfarin, the MedTake test was used. MedTake was developed by Raehl et al. (2002) (14) in order to evaluate the knowledge about prescribed oral drugs of elderly patients. Four parameters (dose of medication, indications for taking the drug, co-ingestion of the drug with food or water and drug regimen) are evaluated for each drug via this scale. For each parameter, the patients obtain scores of over 25. The composite score is 100 for each drug. The higher the score is, the better the knowledge (15).

Hospital Anxiety and Depression Scale: This scale was developed by Zigmond and Snaith (1983) (16) and adapted to Turkish by Aydemir et al. (1997) (17). It is a self-evaluation scale including 14 items, and it evaluates anxiety and depression. The answers are evaluated as quadruple likert-type. The cut-off score is 10 for anxiety and 7 for depression.

Mini Mental State Examination: The MMSE was developed by Folstein et al. (1975) (18) in order to evaluate mental dysfunction, and was adapted to Turkish by Kucukdeveci et al. (2005) (19). It is a widely-used tool in clinical studies and practice. The scale evaluates five basic mental functions (orientation, memory, attention, calculation, and language). The maximum score that can be obtained from the scale is 30 ; lower scores indicate worse mental function.

Barthel Index of Daily Activities: This index has been used in order to evaluate dependency in the daily activities of patients with neurologic disorders. It was adapted to Turkish by Küçükdeveci et al. (2000) (20). The score ranges between 0 and 100 , where 0 indicates complete dependency and 100 indicates independence (21).

Modified Rankin Disability Scale: This scale was developed by Van Swieten et al. (1988) (22) to determine the functional state of patients. According to the score obtained in the mRS, 1 and 2 indicate independence, and 3 and higher indicate dependency.

EQ-5D Scale: The EQ-5D is a standardized instrument developed by the EuroQol Group for use as a measure of health outcome. Its EQ-5D VAS item provides a single index value for health status (23). 


\section{Statistical Analysis}

The SPSS 21.0 (IBM SPSS Inc., Armonk, NY) statistics program was used for the statistical analysis. Normality analysis was performed using the Kolmogorov-Smirnov test in order to define the types of tests in comparisons. Non-parametric tests were used for comparisons because the distribution of the data did not fit to normal distribution. Descriptive statistics (percentages, mean, standard deviation) were used to display sample characteristics, and the Mann-Whitney $\mathrm{U}$ test was used for the comparison of factors affecting drug adherence between two groups. Spearman's correlation analysis was performed for correlational analyses of continuous variables. Stepwise logistic regression analysis was used in order to determine the predictors of adherence. The results were evaluated within the $95 \%$ confidence interval, and a $\mathrm{p}$ value of $<0.05$ was accepted as significant.

\section{Results}

The mean age of the sample was $68.6 \pm 8.9$ (range, 46-93) years. Among the included 99 patients, $54(54.5 \%)$ were male and half of the group was illiterate. The mean duration of diagnosis was $5.9 \pm 3.4$ years. The patients had been using the anticoagulant agent for a mean of $4.2 \pm 3.3$ (range, $0.5-13$ ) years (Table 1).

The characteristics of drug use are presented in Table 2. Of the patients, two-thirds were taking medications without assistance $(62.6 \%)$, and one-third had experienced drug-related adverse effects (33.3\%). The majority of the patients $(72.7 \%)$ had undergone regular INR monitoring.

Mean scores of the scales used in the study are presented in Table 3. The mean MedTake score of the patients was $78.5 \pm 17.2$ (range, 35-100). The mean adherence score was 3.3 $31.1(0-4)$. Twenty percent of the patients were non-adherent.

Table 1. Sociodemographic and disease characteristics of the patients

\begin{tabular}{lll} 
Characteristics & $\mathbf{n}$ & $\%$ \\
Sex & & \\
Male & 54 & 54.5 \\
Female & 45 & 45.5 \\
Education & & \\
Illiterate & 47 & 47.5 \\
Literate & 52 & 52.5 \\
Employment & & \\
Employed & 10 & 10.1 \\
Housewife & 34 & 34.3 \\
Retired & 55 & 55.6 \\
Marital status & & \\
Single/divorced/widow & 41 & 41.4 \\
Married & 58 & 58.6 \\
Age (Mean \pm SD, range) & $68.6 \pm 8.9$ & $46-93$ \\
Time since diagnosis (years) (Mean \pm SD, & $5.9 \pm 3.4$ & $1-14$ \\
range) & & \\
$\begin{array}{lll}\text { Duration of anticoagulant use (years) } \\
\text { (Mean } \pm \text { SD, range) }\end{array}$ & $4.2 \pm 3.3$ & $0.5-13$ \\
SD: Standard deviation & & \\
\hline
\end{tabular}

When drug adherence was compared between subgroups according to the sociodemographic, disease-related and drug userelated characteristics, some significant differences were found (Table 4). A significant negative correlation was determined between age and drug adherence $(r=-0.39, \mathrm{p}<0.001)$. The drug adherence scores were lower in illiterate patients compared to the literate $(3.00 \pm 1.26$ vs. $3.57 \pm 0.95, \mathrm{p}=0.007)$ and in single/ divorced/widows compared to the married $(3.02 \pm 1.32$ vs $3.50 \pm 0.95, p=0.053)$. Drug adherence was worse in patients who had been hospitalized within the last year compared to those who had not $(2.45 \pm 1.56$ vs $3.55 \pm 0.85, \mathrm{p}=0.001)$. Besides, a significant negative correlation was determined between the number of risk factors and adherence $(r=-0.33, p<0.001)$. A significant negative correlation was observed between the duration of anticoagulant use and adherence $(r=-0.52, p<0.001)$. The mean drug adherence scores were lower in patients receiving their drugs with the help of other people compared to self-users $(2.97 \pm 1.21$ vs $3.50 \pm 1.05$, $\mathrm{p}=0.005)$, in those had experienced drug-related adverse effect compared to those that did not $(2.93 \pm 1.32$ vs $3.49 \pm 1.00$, $\mathrm{p}=0.018$ ).

\begin{tabular}{|lcl|}
\hline Table 2. Drug use characteristics of the patients & \\
Characteristics & $\mathrm{n}$ & $\%$ \\
Taking medications without assistance & 62 & 62.6 \\
Regular INR and PT monitoring & 72 & 72.7 \\
$\begin{array}{l}\text { Experiencing drug-related adverse effects } \\
\text { Getting knowledge on the use of the }\end{array}$ & 33 & 33.3 \\
$\begin{array}{l}\text { drugs } \\
\text { Documenting drug use }\end{array}$ & 97.0 \\
$\begin{array}{l}\text { Carrying identity card about drug use } \\
\text { INR: International normalized ratio, PT: Prothrombin time }\end{array}$ & \\
\hline
\end{tabular}

Table 3. Mean scores of the scales

\begin{tabular}{|c|c|c|}
\hline Characteristics & Mean \pm SD & Range \\
\hline HADS: Anxiety & $8.5 \pm 4.5$ & $0-17$ \\
\hline HADS: Depression & $9 \pm 4.3$ & $0-20$ \\
\hline MMSE & $25.3 \pm 4.4$ & $16-32$ \\
\hline Modified rankin scale & $1.8 \pm 1.4$ & $0-5$ \\
\hline Barthel & $82.6 \pm 16.3$ & $45-100$ \\
\hline EQ-5D $D_{\text {VAS }}$ & $59.3 \pm 23.9$ & $5-100$ \\
\hline $\begin{array}{l}\text { MedTake: Total } \\
\text { MedTake: Dose } \\
\text { MedTake: Indications } \\
\text { MedTake: Regimen } \\
\text { MedTake: Coingestion }\end{array}$ & $\begin{array}{l}78.5 \pm 17.2 \\
22.4 \pm 3.3 \\
20.0 \pm 4.8 \\
19.7 \pm 4.8 \\
16.4 \pm 8.0\end{array}$ & $\begin{array}{l}35-100 \\
10-25 \\
10-25 \\
5-25 \\
0-25\end{array}$ \\
\hline $\begin{array}{l}\text { Poor knowledge according to the } \\
\text { MedTake (n, \%) }\end{array}$ & $\mathrm{n}=42$ & $42.4 \%$ \\
\hline $\begin{array}{l}\text { Adherence: Score } \\
\text { Moderate or low adherence (n, \%) } \\
\text { High adherence (n, \%) }\end{array}$ & $\begin{array}{l}3.3 \pm 1.1 \\
n=20 \\
n=79\end{array}$ & $\begin{array}{l}0-4 \\
20.2 \% \\
79.8 \%\end{array}$ \\
\hline
\end{tabular}


The relationship between drug adherence and knowledge regarding drug use (MedTake), functional state (Barthel, Rankin, MMSE), anxiety and depression (HADS) and quality of life (EQ-5D) scores have been presented in Table 4. Significant

Table 4. Drug adherence according to the sociodemographic, disease-related, and drug use-related characteristics of the patients

\begin{tabular}{|c|c|c|c|}
\hline Sociodemographics & Mean $\pm S D$ & Median & $\mathrm{p}$ \\
\hline Age (rho, p) & & $\mathrm{rho}=-0.39$ & $<0.001$ \\
\hline $\begin{array}{l}\text { Sex } \\
\text { Male } \\
\text { Female }\end{array}$ & $\begin{array}{l}3.25 \pm 1.16 \\
3.36 \pm 1.12\end{array}$ & $\begin{array}{l}4.0 \\
4.0\end{array}$ & 0.617 \\
\hline $\begin{array}{l}\text { Educational status } \\
\text { Illiterate } \\
\text { Literate }\end{array}$ & $\begin{array}{l}3.00 \pm 1.26 \\
3.57 \pm 0.95\end{array}$ & $\begin{array}{l}4.0 \\
4.0\end{array}$ & 0.007 \\
\hline $\begin{array}{l}\text { Marital status } \\
\text { Single/divorced/widow } \\
\text { Married }\end{array}$ & $\begin{array}{l}3.02 \pm 1.32 \\
3.50 \pm 0.95\end{array}$ & $\begin{array}{l}4.0 \\
4.0\end{array}$ & 0.053 \\
\hline \multicolumn{4}{|l|}{ Disease-related characteristics } \\
\hline $\begin{array}{l}\text { Affected hemisphere } \\
\text { Right } \\
\text { Left }\end{array}$ & $\begin{array}{l}3.36 \pm 1.15 \\
3.17 \pm 1.13\end{array}$ & $\begin{array}{l}4.0 \\
4.0\end{array}$ & 0.214 \\
\hline $\begin{array}{l}\text { Hospitalization within last } \\
\text { year } \\
\text { Present } \\
\text { Absent }\end{array}$ & $\begin{array}{l}2.45 \pm 1.56 \\
3.55 \pm 0.85\end{array}$ & $\begin{array}{l}3.0 \\
4.0\end{array}$ & 0.001 \\
\hline $\begin{array}{l}\text { Number of risk factors } \\
\text { (rho, p) }\end{array}$ & & $\mathrm{rho}=-0.33$ & 0.001 \\
\hline \multicolumn{4}{|l|}{ Drug use-related characteristics } \\
\hline $\begin{array}{l}\text { Duration of anticoagulant } \\
\text { use (rho, p) }\end{array}$ & & $\mathrm{rho}=-0.52$ & $<0.001$ \\
\hline $\begin{array}{l}\text { Taking medication w/o } \\
\text { assistance } \\
\text { Yes } \\
\text { No }\end{array}$ & \multicolumn{2}{|c|}{$\begin{array}{l}\text { Taking medication w/o } \\
\text { assistance }\end{array}$} & 0.005 \\
\hline \multicolumn{3}{|l|}{$\begin{array}{l}\text { Regular INR and PT } \\
\text { monitoring }\end{array}$} & 0.034 \\
\hline $\begin{array}{l}\text { Drug-related adverse effect } \\
\text { Experienced } \\
\text { Not-experienced }\end{array}$ & $\begin{array}{l}2.93 \pm 1.32 \\
3.49 \pm 1.00\end{array}$ & $\begin{array}{l}4.0 \\
4.0\end{array}$ & 0.018 \\
\hline $\begin{array}{l}\text { Documenting drug use } \\
\text { Yes } \\
\text { No }\end{array}$ & $\begin{array}{l}3.29 \pm 1.15 \\
3.31 \pm 1.13\end{array}$ & $\begin{array}{l}4.0 \\
4.0\end{array}$ & 0.936 \\
\hline \multicolumn{3}{|l|}{$\begin{array}{l}\text { Carrying ID card about drug } \\
\text { use }\end{array}$} & 0.262 \\
\hline \multicolumn{4}{|c|}{$\begin{array}{l}\text { Mann-Whitney U test was used to compare groups. Spearman was used for } \\
\text { correlation analysis. } \\
\text { INR: International normalized ratio, PT: Prothrombin time, SD: Standard } \\
\text { deviation }\end{array}$} \\
\hline
\end{tabular}

correlations were determined between drug adherence and all parameters.

In order to eliminate the effects of independent variables, originated from the relationships between themselves, independent variables that were determined to be significant underwent regression analysis (Table 5). Variables that were included in the model were age, education, hospitalization, self-use of the drug, adverse effects, MedTake, HADS anxiety and depression, MMSE, Barthel, and Rankin. Backward stepwise regression analysis was performed in nine steps and revealed that predictors of the adherence were having experienced adverse effects, knowledge regarding drugs (MedTake) and depression (HADS) $\left(\mathrm{R}^{2}=0.482\right.$; $\mathrm{p}=0.001 ; \mathrm{p}<0.05)$ (Table 6).

\section{Discussion}

Warfarin is still one of the most commonly used drugs in the secondary prevention of stroke, although some novel agents have been developed. In previous studies on warfarin treatment, the most commonly studied subject was the efficacy/safety of the drug (24). In this study, adherence to warfarin treatment and factors that might affect adherence were investigated.

Eighty percent of our patients reported adherence to warfarin. It is difficult to interpret this result because different methods have been employed to assess adherence in different studies and there are limited studies in patients with stroke. In real-world observational studies, adherence to warfarin has been reported lower (between 56-75\%). However, the majority of these earlier studies were conducted on patients with AF or thromboembolism $(25,26,27,28,29)$. There is also a nationwide study conducted in Turkey on adherence to warfarin (30), but because this study was conducted in a mixed patient group and "time in therapeutic range method" was used in this study to assess adherence, it may not be appropriate to compare our results. There are only a few studies on stroke patients presenting self-report adherence rates. These studies reported varying rates for high adherence (between $50 \%$

Table 5. Correlations between drug adherence and the MedTake, HADS, MMSE, Barthel, Rankin, and EQ-5D

\begin{tabular}{lll} 
Scales & rho & p \\
MedTake: Dose & 0.28 & 0.004 \\
MedTake: Indications & 0.48 & 0.001 \\
MedTake: Regimen & 0.57 & 0.001 \\
MedTake: Coingestion & 0.50 & 0.001 \\
MedTake: Total & 0.56 & 0.001 \\
HADS-anxiety & -0.45 & 0.001 \\
HADS-depression & -0.42 & 0.001 \\
MMSE & 0.50 & 0.001 \\
Barthel index & 0.52 & 0.001 \\
Rankin & -0.46 & 0.001 \\
EQ-5D & 0.45 & 0.001 \\
$\begin{array}{l}\text { Spearman correlation analysis was used. } \\
\text { EQ-5D } \\
\text { and depression scale, MMSE: Mini mental state examination: }\end{array}$ \\
\hline
\end{tabular}




\begin{tabular}{|lcccccccc|}
\hline \multicolumn{7}{|l|}{ Table 6. Stepwise regression analysis in order to determine predictors of adherence } \\
Variables & Beta & SE & Wald & p & OR & \multicolumn{2}{c|}{ 95\% CI } \\
& & & & & & Lower & Upper \\
Adverse effects & -1.540 & 0.671 & 5.276 & 0.022 & 0.214 & 0.058 & 0.798 \\
MedTake & 0.075 & 0.023 & 10.690 & 0.001 & 1.078 & 1.031 & 1.128 \\
HADS-Depression & -0.229 & 0.103 & 4.947 & 0.026 & 0.795 & 0.650 & 0.973 \\
Constant & -1.065 & 2.013 & 0.280 & 0.597 & 0.345 & & \\
CI: Confidence interval, OR: Odds ratio, SE: Standard error, HADS: Hospital anxiety and depression scale
\end{tabular}

and $84 \%)(31,32,33)$. Our findings should be interpreted carefully because the assessment of adherence with a patient self-report approach may cause bias. Especially in face-to-face interviews, patients may omit to provide some information and therefore adherence may be overestimated. This explanation suggested by Rossi et al. (2018) (29) would partially explain the discrepancy between the (inadequate) knowledge and (high) adherence in our sample, and also the inconsistency between our adherence rates and our national adherence rates. On the other hand, prior stroke, as a dramatic life event, may in itself be an adherence-enhancing factor, as previously suggested by Polymeris et al. (2016) (32). This may explain the lower adherence rates in observational studies in mixed populations as compared with our study, which included only patients with stroke. Another issue that should be considered in adherence studies on patients with stroke is family involvement (34). Family involvement in medication management should be investigated, especially in collectivist cultures such as in Turkey.

Drug adherence was better in patients who were younger and literate and married (due to caregiver support) and was not affected by their sex $(7,11,31)$. The findings of earlier studies were similar to our study with regard to age, educational status, and marital status, whereas male sex was related to poor drug adherence $(7,27)$. No effect of sex on drug adherence observed in this study was believed to be due to the female patients having a lower educational status than the male patients. In contrast to the current time, in the studied generation, the educational status varied between the two sexes, and this was reflected in our sample.

In terms of disease-related factors that may impact adherence, an increased number of risk factors was observed to be associated with drug adherence. As known, the presence of concomitant diseases in elderly patients causing polypharmacy reduces drug adherence $(35,36,37)$. In our study, hospitalization within the previous year was also found to be associated with poor drug adherence. Another factor that may impact adherence is the duration of drug use. In our study, the duration of warfarin use was correlated with drug adherence negatively. Long-term warfarin has a risk of hemorrhage and also requires lifestyle modifications such as regular INR monitoring, considering drug-food or drug-drug interactions, and coping with the fear of experiencing adverse effects; therefore, it may complicate drug adherence $(7,11,35)$. The adherence scores of patients who attended regular INR monitoring were better than those who did not. Another important subject in patients under warfarin treatment is carrying a note (such as identity card/document or wristband) showing the use of the drug and also documenting the use of their medications. However, in our sample, these habits were not found to be associated with drug adherence (38). Drug adherence was poorer in patients receiving their drugs with the help of other people (family members) compared with selfusers. There is a knowledge gap in the stroke literature about factors that influence adherence in survivors of stroke with severe disability and the role of their caregivers in patients' adherence $(34,38)$. Moreover, other variables such as patients' characteristics (age, education, drug knowledge score, anxiety and depression, MMSE, mRS, and Barthel) and caregiver characteristics and continuity of the same caregiver may impact adherence. Another factor that was found to be associated with adherence was experiencing adverse effects. This factor was also found to be a predictor of adherence. Causing fear and frustration, experiencing adverse effects may result in non-adherence (34).

In our study, univariate analysis showed significant correlations between drug adherence and functional state (Barthel, mRS, MMSE) and HADS (anxiety and depression). Furthermore, depression was determined to be an independent predictor of drug adherence in the regression analysis. Disability has been reported as one of the factors that impairs drug adherence because disabled patients would be dependent on other people for drug use, thus drug adherence was reported to be poor $(28,39,40)$. In our study, significant correlations were obtained between the functional state (measured using the Barthel and mRS scales) and drug adherence, and better adherence scores were obtained in self-drug users, and these findings support this suggestion. One of the factors that may affect drug adherence is mental state. Impaired cognition was reported as a predictor of non-adherence (7). Cognitively impaired patients cannot easily afford the high degree of adherence that anticoagulants require. Our study also confirmed the findings of earlier studies conducted on different patient groups, which revealed a relation between depression and anxiety and poor adherence $(41,42)$. When the relationship between drug adherence and knowledge regarding the drug was investigated, moderate positive correlations were determined between these variables. The regression analysis revealed that knowledge on the drug was an independent predictor of adherence. This finding was similar to those obtained in other studies $(28,33,43,44)$. A positive correlation was determined between adherence and the quality of life in our study. This may have resulted from the fact that patients with a better quality of life may have adjusted to the stroke better and therefore they may be ready to adhere to the drug treatment (45).

Oral anticoagulants are widely used in patients with stroke for secondary prevention. Healthcare professionals should be aware of patients who have risk factors for non-adherence. Prevention of non-adherence can contribute to improved patient outcomes in 
stroke. This research has made a contribution to the knowledge base of risk factors for non-adherence in patients with stroke.

\section{Study Limitations}

There are some limitations of this study. These include the small sample size, lack of follow-up, lack of evaluation at to whether the INR level was within the therapeutic range, and lack of evaluation of adherence using more objective methods (e.g. pill counting). Future studies are recommended to address these limitations.

\section{Conclusion}

In conclusion, although the majority of our sample reported adherence it was observed that more than $40 \%$ the patients had poor knowledge regarding the drug. Drug adherence was determined to be related to some sociodemographic and clinical factors and functional state. Experiencing adverse effects, knowledge about the drug, and depression were determined to be predictors of adherence. Also, adherence was found to have a relationship with quality of life. Therefore, in order to improve drug adherence, patients should be assessed for depression and given training regarding drug use, especially on what to do if an adverse event occurs.

\section{Ethics}

Ethics Committee Approval: Ethical approval was obtained from the Ethics Board of the Istanbul Training and Research Hospital (25.11.2016/892).

Informed Consent: Written informed consent was obtained from the participants.

Peer-review: Externally and internally peer-reviewed.

\section{Authorship Contributions}

Concept: Z.T., Design: Z.T., Data Collection or Processing: C.P.D., R.R.Ç., Analysis or Interpretation: Z.T., C.P.D., Literature Search: Z.T., C.P.D., R.R.Ç., Writing: Z.T., C.P.D., R.R.Ç., H.D.

Conflict of Interest: No conflict of interest was declared by the authors.

Financial Disclosure: The authors declared that this study received no financial support.

\section{References}

1. Benjamin EJ, Blaha MJ, Chiuve SE, et al. Heart disease and stroke statistics-2018 update: a report from the American Heart Association. Circulation 2017;135:146603.

2. Ince B. Atrial fibrillation and stroke: secondary prophylaxis. Arch Turk Soc Cardiol 2013;41:19-24.

3. January CT, Wann LS, Alpert JS, et al. 2014 AHA/ACC/HRS guideline for the management of patients with atrial fibrillation a report of the American College of Cardiology/american Heart Association task force on practice guidelines and the heart rhythm society. Circulation 2014;130:2071-2104.

4. Başaran Ö, Beton O, Doğan V, et al. ReAl-life Multicenter Survey Evaluating Stroke prevention strategies in non-valvular atrial fibrillation (RAMSES study). Anatol J Cardiol 2016;16:734-741.

5. Potpara TS, Dan GA, Trendafilova E, et al. Stroke prevention in atrial fibrillation and 'real world' adherence to guidelines in the Balkan Region: The BALKANAF Survey. Sci Rep 2016;12:20432.

6. Cruess DG, Localio AR, Platt AB, et al. Patient attitudinal and behavioral factors associated with warfarin non-adherence at outpatient anticoagulation clinics. Int J Behav Med 2010;17:33-42.

7. Kneeland PP, Fang MC. Current issues in patient adherence and persistence: focus on anticoagulants for the treatment and prevention of thromboembolism. Patient Prefer Adherence 2010;24:51-60.
8. Ababneh MA, Al-Azzam SI, Alzoubi KH, Rababa'h AM. Adherence in outpatients taking warfarin and its effect on anticoagulation control in Jordan. Int J Clin Pharm 2016;38:816-821.

9. Davis NJ, Billett HH, Cohen HW, Arsten JH. Impact of adherence, knowledge, and quality of life on anticoagulation control. Ann Pharmacother 2005;39:632636.

10. Hannon N, Arsava EM, Audebert HJ, et al. Antithrombotic treatment at onset of stroke with atrial fibrillation, functional outcome, and fatality: a systematic review and meta-analysis. Int J Stroke 2015;10:808-814.

11. Mayet AY. Patient adherence to warfarin therapy and its impact on anticoagulation control. Saudi Pharm J 2016;24:29-34.

12. Witt DM, Delate T, Clark NP, et al. Nonadherence with INR monitoring and anticoagulant complications. Thromb Res 2013;132:124-130.

13. Morisky DE, Green LW, Levine DM. Concurrent and predictive validity of a selfreported measure of medication adherence. Med Care 1986;24:67-74.

14. Raehl CL, Bond CA, Woods T, Patry RA, Sleeper RB. Individualized drug use assessment in the elderly. Pharmacotherap 2002;22:1239-1248.

15. Gomes DC, Costa-Paiva L, Farhat FC, Pedro AO, Pinto-Neto AM. Ability to follow anti-reabsorptive drug treatment in postmenopausal women with reduced bone mass. Menopause 2011;18:531-536.

16. Zigmond AS, Snaith RP. The hospital anxiety and depression scale. Acta Psychiatr Scand 1983;67:361-370.

17. Aydemir O, Guvenir T, Küey L, Kültür S. Hastane anksiyete ve depresyon ölçeği Türkçe formunun geçerlilik ve güvenilirlik çalışması. Türk Psikiyatri Dergisi 1997;8:280-287.

18. Folstein MF, Folstein SE, McHugh PR. "Mini-mental state": a practical method for grading the cognitive state of patients for the clinician. J Psychiatr Res $1975 ; 12: 189-198$.

19. Küçükdeveci AA, Kutlay S, Elhan AH, Tennant A. Preliminary Study to Evaluate The Validity of The Mini-Mental State Examination In A Normal Population In Turkey. Int J Rehabil Res 2005;28:77-79.

20. Küçükdeveci AA, Yavuzer G, Tennant A, Süldür N, Sonel B, Arasil T. Adaptation of the modified Barthel Index for use in physical medicine and rehabilitation in Turkey. Scand J Rehabil Med 2000;32:87-92.

21. Gresham GE, Duncan PW, Stason WB, et al. Post-Stroke Rehabilitation. Clinical Practice Guideline, No. 16. U.S. Department of Health and Human Services. Public Health Service, Agency for Health Care Policy and Research; Rockville, MD: 1995. AHCPR Publication No. 95-0662.

22. Van Swieten JC, Koudstaal PJ, Visser MC, Schouten HJ, van Gijn J. Interobserver agreement for the assessment of handicap in stroke patients. Stroke 1988;19:604607.

23. Kaya N, Solmaz F, Bolol N. Larinjektomili bireylerin sağlıga ilişkin yasam kalitesini degerlendirmede EuroQol ölçeğinin güvenirlik ve geçerliği. İ.Ü.F.N Hem Derg 2007;15:30-39.

24. Platt $\mathrm{AB}$, Localio $\mathrm{AR}$, Brensinger $\mathrm{CM}$, et al. Can we predict daily adherence to warfarin?: Results from the International Normalized Ratio Adherence and Genetics (IN-RANGE) Study. Chest 2010;137:883-889.

25. Amara W, Larsen TB, Sciaraffia E, et al. Patients' attitude and knowledge about oral anticoagulation therapy: results of a self-assessment survey in patients with atrial fibrillation conducted by the European Heart Rhythm Association. Europace 2016;18:151-155.

26. Benzimra M, Bonnamour B, Duracinsky M, et al. Real-life experience of quality of life, treatment satisfaction, and adherence in patients receiving oral anticoagulants for atrial fibrillation. Patient Prefer Adherence 2018;12:7987.

27. Castellucci LA, Shaw J, van der Salm K, et al. Self-reported adherence to anticoagulation and its determinants using the Morisky medication adherence scale. Thromb Res 2015;136:727-731.

28. Emren SV, Şenoz O, Bilgin M, et al. Drug Adherence in patients with nonvalvular atrial fibrillation taking non-vitamin $\mathrm{K}$ antagonist oral anticoagulants in Turkey: NOAC-TR. Clin Appl Thromb Hemost 2018;24:525-531.

29. Rossi AP, Facchinetti R, Ferrari E, et al. Predictors of self-reported adherence to direct oral anticoagulation in a population of elderly men and women with nonvalvular atrial fibrillation. J Thromb Thrombolysis 2018;46:139-144.

30. Çelik A, İzci S, Kobat MA, et al. The awareness, efficacy, safety, and time in therapeutic range of warfarin in the Turkish population: WARFARIN-TR. Anatol J Cardiol 2016;16:595-600. 
31. Luger S, Hohmann C, Niemann D, et al. Adherence to oral anticoagulant therapy in secondary stroke prevention - impact of the novel oral anticoagulants. Patient Prefer Adherence 2015;23:1695-1705.

32. Polymeris AA, Traenka C, Hert L, et al. Frequency and determinants of adherence to oral anticoagulants in stroke patients with atrial fibrillation in clinical practice Eur Neurol 2016; 76:187-193.

33. Rolls CA, Obamiro KO, Chalmers L, et al. The relationship between knowledge, health literacy, and adherence among patients taking oral anticoagulants for stroke thromboprophylaxis in atrial fibrillation. Cardiovasc Ther 2017;35.

34. De Simoni A, Mant J, Sutton S. Adherence to medication in stroke survivors dependent on caregivers. Br J Gen Pract 2015;65:789-791.

35. Di Minno A, Spadarella G, Tufano A, et al. Ensuring medication adherence with direct oral anticoagulant drugs: lessons from adherence with vitamin $\mathrm{K}$ antagonists (VKAs). Thromb Res 2014;133:699-704.

36. Pasina L, Brucato AL, Falcone $\mathrm{C}$, et al. Medication non-adherence among elderly patients newly discharged and receiving polypharmacy. Drugs Aging 2014;31:283-289

37. Jansà M, Hernández C, Vidal M, et al. Multidimensional analysis of treatment adherence in patients with multiple chronic conditions. A cross-sectional study in a tertiary hospital. Patient Educ Couns 2010;81:161-168.

38. Al AlShaikh S, Quinn T, Dunn W, et al. Multimodal interventions to enhance adherence to secondary preventive medication after stroke: a systematic review and meta-analyses. Cardiovasc Ther 2016;34:85-93.
39. Galindo-Ocaña J, Ortiz-Camúñez Mde L, Gil-Navarro MV, et al. Disability as a barrier to drug adherence in polypathological patients: role of main carer. Rev Clin Esp 2010;210:221-226.

40. Horstmann S, Rizos T, Saribas M, et al. Cognitive impairment is not a predictor of failure to adhere to anticoagulation of stroke patients with atrial fibrillation. Cerebrovasc Dis 2015;39:325-331.

41. El-Gatit AM, Haw M. Relationship between depression and non-adherence to Anticoagulant therapy after valve replacement. East Mediterr Health J 2003;9:12-19.

42. Rose AJ, Miller DR, Ozonoff A, et al. Gaps in monitoring during oral anticoagulation: insights into care transitions, monitoring barriers, and medication nonadherence. Chest 2013;143:751-757.

43. Wang Y, Kong MC, Lee LH, et al. Knowledge, satisfaction, and concerns regarding warfarin therapy and their association with warfarin adherence and anticoagulation control. Thromb Res 2014;133:550-554.

44. Zhao S, Zhao H, Wang L, et al. Education is critical for medication adherence in patients with coronary heart disease. Acta Cardiol 2015;70:197-204.

45. Bushnell CD, Zimmer LO, Pan W, et al. Persistence with stroke prevention medications 3 months after hospitalization. Arch Neurol 2010;67:1456-1463. 